Bioscientia Medicina: Journal of Biomedicine \&

Translational Research

Journal Homepage: www.bioscmed.com

\title{
Characteristics of Cholelithiasis Patients in Dr. Achmad Mochtar General Hospital Bukittinggi on January 2019 - December 2020
}

\section{Muhammad Reza Azriyantha ${ }^{1 *}$, Ambiar Manjas ${ }^{1}$}

${ }^{1}$ Department of Surgery, Dr Achmad Mochtar General Hospital, Bukittinggi, Indonesia

\author{
A R T I C L E I N F O \\ Keywords: \\ Cholelithiasis \\ Descriptive study \\ Cholecystectomy \\ Abdominal pain
}

\section{*Corresponding author:}

Muhammad Reza Azriyantha

\section{E-mail address: \\ ejabagan@gmail.com}

All authors have reviewed and approved the final version of the manuscript.

\section{https://doi.org/10.37275/bsm.v6i2.451}

\begin{abstract}
A B S T R A C T
Background. Cholelithiasis is a condition where there are stones in the gallbladder or the common bile duct or both. This study aims to describe the characteristics of cholelithiasis patients in RSUD Dr. Achmad Mochtar Bukittinggi.

Methods. This research is a descriptive observational study on the incidence of cholelithiasis in hospitals. Dr. Achmad Mochtar Bukittinggi period January 2019 December 2020. A total of 224 research subjects participated in this study. Secondary data was collected from medical records of research subjects, including data on age, gender, body mass index, clinical symptoms, and type of surgery. Data analysis was carried out with the help of SPSS 25 software.

Results. Cholelithiasis was most commonly found in the age group over 50 years $(47.8 \%)$, normal BMI (46\%) cases. The most complained symptom in cholelithiasis patients in this study was abdominal pain $(61.6 \%)$. All cholelithiasis patients $(100 \%)$ in this study underwent laparoscopic cholecystectomy surgery.

Conclusion. Cholelithiasis patients who underwent surgery in hospitals. Dr. Achmad Mochtar Bukittinggi for the period January 2019 - December 2020 were 224 patients. The majority of patients over 50 years of age, women, had a normal BMI. The patient frequently complained of abdominal pain and all had undergone laparoscopic cholecystectomy.
\end{abstract}


suffer from cholelithiasis, and in the population, over 80 years the incidence of cholelithiasis is $25 \%-30 \% .^{7}$ Cholelithiasis is more common in women than men. A study states that the prevalence of cholelithiasis in the United States is $7.9 \%$ in men and $16.6 \%$ in women. The ratio of the incidence of cholelithiasis in men and women is $3: 1$, and in the sixth and seventh decades of life the ratio gets smaller. ${ }^{8}$ In addition to age and sex, the incidence of cholelithiasis is also affected by obesity, pregnancy, glucose intolerance, insulin resistance, diabetes mellitus, hypertriglyceridemia, diet, Crohn's disease, resection of the terminal ileus, and other factors. 9

Cholelithiasis is usually in the gallbladder, but cholelithiasis can also be in the bile ducts when stones in the gallbladder migrate and are called secondary bile duct stones. Approximately $10 \%-15 \%$ of patients with stones in the gallbladder also have stones in the bile ducts. Stones in the bile duct can also form without involving the gallbladder, referred to as primary bile duct stones. Most of the patients (80\%) with cholelithiasis were asymptomatic, only a few patients complained of colic pain. 10

Based on the description above, there are variations not typical in patients with cholelithiasis and clinical symptoms were also still quite varied. This study provides an overview of the characteristics of cholelithiasis patients in RSUD RSUD. Dr. Achmad Mochtar Bukittinggi, so it is hoped that it can provide an overview of the characteristics of cholelithiasis patients.

\section{Methods}

This research is a descriptive observational study on the incidence of cholelithiasis in hospitals. Dr. Achmad Mochtar Bukittinggi for the period January 2019 December 2020. The subjects of this study were Cholelithiasis sufferers who were treated at the RSUD. Dr. Achmad Mochtar Bukittinggi in the research period, with a sampling technique total of sampling. A total of 224 research subjects participated in this study. Secondary data was collected from medical records of research subjects, including data on age, gender, body mass index, clinical symptoms, and type of surgery. The inclusion criteria were patients with a diagnosis of cholelithiasis and surgery at Dr. Hospital. Achmad Mochtar Bukittinggi for the period January 2019 - December 2020 based on medical records and patient medical record data, there are variables of age, gender, Body Mass Index, symptoms complained of and the type of surgery performed on the patient. Data analysis was performed with the help of SPSS 25 software. Univariate analysis was performed to assess the frequency distribution of respondents' age, sex, body mass index, clinical symptoms, and type of surgery. The frequency distribution is presented with frequency and percentage.

\section{Results}

Table 1. Number of cases of cholelithiasis in RSUD Dr. Achmad Mochtar Bukittinggi Period January 2019 - December 2020

\begin{tabular}{|c|c|c|}
\hline Case & Frequency (Person) & \% \\
\hline January - December 2019 & 128 & 43 \\
\hline January - December 2020 & 96 & 100 \\
\hline Total & 224 & 43 \\
\hline
\end{tabular}

Based on Table 1 it is known that the number of cholelithiasis cases in RSUD Dr. Achmad Mochtar Bukittinggi Period January 2019 - December 2020, which is 224 cases. Where 128 cases in 2019 and 96 cases in 2020 
Table 2. Distribution of frequency and percentage of cholelithiasis patients by age

\begin{tabular}{|c|c|c|}
\hline \multirow{2}{*}{ Age (years) } & \multicolumn{2}{|c|}{ Cholelithiasis } \\
\cline { 2 - 4 } & Frequency (person) & 6.3 \\
\hline$<30$ & 14 & 46 \\
\hline $30-50$ & 103 & 47,8 \\
\hline$>50$ & 107 & 100 \\
\hline
\end{tabular}

Based on Table 2, it is known that the highest number of cases of cholelithiasis was found in the age group over 50 years, namely 107 (47.8\%) cases and the least in the age group less than 30 years, namely 14 $(6.3 \%)$ cases.

Table 3. Distribution of frequency and percentage of cholelithiasis patients by gender

\begin{tabular}{|c|c|c|}
\hline \multirow{2}{*}{ Gender } & \multicolumn{2}{|c|}{ Cholelithiasis } \\
\cline { 2 - 3 } & Frequency (person) & 33.9 \\
\hline Male & 76 & 66.1 \\
\hline Female & 148 & 100 \\
\hline Total & 224 & $\%$ \\
\hline
\end{tabular}

Table 4. Distribution of frequency and percentage of cholelithiasis patients based on BMI (Body Mass Index)

\begin{tabular}{|c|c|c|}
\hline \multirow{2}{*}{ BMI } & \multicolumn{2}{|c|}{ Cholelithiasis } \\
\cline { 2 - 3 } & Frequency & 2.7 \\
\hline Underweight & 6 & 46 \\
\hline Normal & 103 & 18.8 \\
\hline Overweight & 42 & 20.5 \\
\hline Obesity I & 46 & 12.1 \\
\hline Obesity II & 27 & 100 \\
\hline Total & 224 & \\
\hline
\end{tabular}

Based on Table 4 it is known that the most cases of cholelithiasis were found in the group with normal BMI, namely 103 (46\%) cases and the least BMI underweight is $6(2.7 \%)$ cases.

Table 5. Distribution of frequency and percentage of cholelithiasis patients based on the most complained

\begin{tabular}{|c|c|c|}
\hline \multirow{2}{*}{ Symptoms } & \multicolumn{2}{|c|}{ Cholelithiasis } \\
\cline { 2 - 3 } & Frequency (person) & 11.2 \\
\hline Bloating & 25 & 20.5 \\
\hline Nausea/vomiting & 46 & 61.6 \\
\hline Abdominal pain & 138 & 6.7 \\
\hline Others & 15 & 100 \\
\hline Total & 224 & $\%$ \\
\hline
\end{tabular}

Based on the Table 5 it is known that the most complained symptom in cholelithiasis patients in this study was abdominal pain in 138 (61.6\%) cases, followed by nausea/vomiting in 46 (20.5\%) cases, then bloating in $25(11,2 \%)$ cases. 
Table 6. Distribution of frequency and percentage of cholecystitis patients by type of surgery performed

\begin{tabular}{|c|c|c|}
\hline \multirow{2}{*}{ Type of Surgery } & \multicolumn{2}{|c|}{ Cholecystitis } \\
\cline { 2 - 3 } & Frequency (person) & \% \\
\hline Laparascopy & 224 & 100 \\
\hline Cholecystectomy & 0 & 0 \\
\hline Open Cholecystectomy & 0 & 0 \\
\hline Total & 224 & 100 \\
\hline
\end{tabular}

Based on Table 6 above, it is known that all Cholecystitis patients $(100 \%)$ in this study received treatment Laparoscopic Cholecystectomy surgery.

\section{Discussion}

The results of the study above stated that the causes of cholelithiasis most were found in the age group over 50 years, namely 107 (47.8\%) cases and the least in the age group less than 30 years, namely 14 $(6.3 \%)$ cases. This is following the study, where the incidence of cholelithiasis is strongly influenced by age, that there is a progressive increase in the incidence of cholelithiasis associated with an increase in a person's age. ${ }^{11}$ Cholelithiasis is more common in women than men. This is also shown in this study, where most cases of cholelithiasis were found in women, namely 148 (66.1\%) cases. The mechanism of gallstone formation in women, especially cholesterol stones is associated with female sex hormones, parity, use of oral contraceptives, and estrogen replacement therapy. 12-15 Obesity is associated with increased cholesterol synthesis in a person's body. About 50\% of obese patients have a history of gallstone surgery, but in this study, the results showed that most cases of cholelithiasis were found in the group of patients with a normal BMI (Body Mass Index) i.e. 103 (46\%) cases, and after that, it was followed by the group patients with BMI Obesity I with 46 (20.5\%) cases. 16.17

A study states that most patients with gallstones are asymptomatic, but others complain of abdominal pain. The pain felt by the patient is colic pain, where this pain is caused by blockage of bile flow from the gallbladder due to stones, or when stones move into the bile duct and block the duct, and inflammation is caused by stones in the gallbladder also causes pain. The pain may radiate to the mid-back, scapula, or the top of the shoulder, accompanied by nausea and vomiting. The same thing was also obtained from the results of this study which obtained data that the symptoms most complained of in cholelithiasis patients in this study were abdominal pain in 138 (61.6\%) cases, followed by symptoms of nausea/vomiting in 46 (20.5\%) case. ${ }^{18-21}$

Laparoscopic cholecystectomy is the treatment of choice for symptomatic gallstones hence medical therapy for gallstones has been reduced. By using this minimally invasive method (laparoscopic cholecystectomy) it is hoped that the healing and recovery process for patients undergoing surgery will be much faster and it is hoped that fewer complications will occur. This makes minimally invasive therapy (laparoscopic cholecystectomy) the best choice at this time in the selection of surgery for cholelithiasis patients. In this study, data was obtained that from January 2019 to December 2020 there were 224 cases of cholelithiasis that underwent surgery at the RSUD Dr. Achmad Mochtar Bukittinggi where all (100\%) minimally invasive surgery (laparoscopic cholecystectomy) was performed, which is expected to allow the patient to recover faster and recover after surgery. $22-24$

\section{Conclusion}

Cholelithiasis patients who underwent surgery in RSUD Dr. Achmad Mochtar Bukittinggi for the period January 2019 - December 2020 were 224 patients. Most of the cholelithiasis patients were more than 50 years old which was 107 (47.8\%) cases. More women suffer from cholelithiasis, namely 148 (66.1\%) cases. 
Based on BMI (BodyIndex)Mass, the most cases of cholelithiasis suffered by the group of patients with BMI normal, namely 103 (46\%) cases, followed by the group of patients with BMI Obesity I with 46 (20.5\%) cases. The symptom most frequently complained of by cholelithiasis patients in this study was abdominal pain. The most common type of surgery performed on patients in this study was Laparoscopic Cholecystectomy.

\section{References}

1. Afdhal NH. Diseases of the gallbladder and bile duct. In: Goldman L, Ausiello D (eds). Cecil medicine. 23rd edition. Philadelphia: Elsevier. 2007

2. Boon NA, Colletigue NR, Walker BR (eds) Davidson's principle and practice of medicine. 20th edition. Philadelphia: Elsevier. 2007; 990993.

3. Caffasso DE, Smith RR Symptomatic cholelithiasis and functional disorders of the biliary tract. In: Wernberg JA (ed). Surgical clinics of North America. Philadelphia: Elsevier. 2014; 94: 233-236.

4. Chang YN, Jang JY, Kwon W, Park JW, Kang $\mathrm{MJ}$, Ryu JK, et al. Changes in demographic features of gallstone disease: 30 years of surgically treated patients. Gut and Liver Journal. 2013; 7(6): 719-24.

5. Chen CY, Lu CL, Huang YS, Tam TN, Chao Y, Chang FY, et al. Age is one of risk factors in developing gallstone disease in Taiwan. Age and aging. 1998; 27: 437-441.

6. Conte D, Fraquelli M, Giunta M, Conti CB Gallstones and liver disease: an overview. J Gastrointestinal Liver Dis. 2011; 20(1): 9-11.

7. Corte CD, Falchetti D, Nebbia G, Calacoci M, Pastore M, Francavilla R, et al. Management of cholelithiasis in Italian Children: A national multicenter study. World Journal of Gastroenterology. 2008; 14(9): 1383-1388.

8. Ginting S. A description characteristic risk factor of the cholelithiasis disease in the
Colombia Asia Medan Hospital. Dharma Agung Journal. 2013; XX: 38-46.

9. Girsang $\mathrm{JH}$, Hiswani, Jemadi Characteristics of cholelithiasis patients who were hospitalized at Santa Elisabeth Hospital Medan in 20102011. University of Northern Sumatra. Essay. 2011.

10. Greenberger NJ, Blumberg RS, Burakoff $R$ Current diagnosis \& treatment of gastroenterology, hepatology, \& endoscopy. Second Edition USA: McGraw-Hill. 2009; 537546.

11. Greenberger NJ, Paumgartner G. Diseases of the gallbladder and bile duct. In: Fauci AS, Kosper DL, Longo D, Braunwald E, Hauser SL, Loscalzo J, et al (eds). Harrison's principle of internal medicine. 18th edition. New York: McGraw-Hill. 2011.

12. Guyton AC, Hall JE. Textbook of medical physiology. 11th edition. Jakarta: EGC. 2006; 1028-32.

13. Hunter JG, Oddsdettir M. Gallbladder and extrahepatic billiary system. In: Brunicardi FC, Andersen DK, Billiar TR, Dunn DL, Hunter JG, Pollock RE (eds). Schwartz's principles of surgery. Eighth edition. New York: McGrawHill. 2007

14. Ko CW, Lee SP. Gallstones. In: Yamada T, Alpers DH, Kallo AN, Kaplowitz N, Owyang C, Powell DW (eds). Textbook of gastroenterology. Fifth edition Volume 1. UK: Blackwell Publishing. 2009; 1952.

15. Kumar P, Clark M. Clinical medicine. Sixth edition. Philadelphia: Elsevier. 2006; 398-403.

16. Kumar V, Abbas AK, Mitchell R, Fausto N Robbins basic pathology. Eighth edition. Philadelphia: Elsevier. 2007; 667.

17. Lesmana LA. Gallstone disease. In: Sudoyo AW, Setiyohadi B, Alwi I, Simadibrata M, Setiati S (eds). Internal medicine textbook. Edition V Volume 1. Jakarta: Department of Internal Medicine FKUI. 2009; 721-726.

18. Marschall HU, Einarsson C. Gallstone disease. Journal of Internal Medicine; 2007; 261: 529542. 
19. Murray RK, Mayes PA, Granner DK, Radwell VW. Clinical biochemistry. 25th edition. Jakarta: EGC. 2003; 633-635.

20. Nuhadi M. Differences in the composition of gallbladder stones with bile duct stones in patients undergoing biliary tract exploration at RSHS Bandung. Padjadjaran University. Dissertation. 2010.

21. Nurman A. Gallstones. In: Sulaiman A, Akbar $\mathrm{N}$, Lesmana LA, Noer S (eds). Heart disease textbook. First edition. Jakarta: Jayabadi. 2007; 161-173.

22. Sherlock S, Dooley J. Diseases of the liver and biliary system. 11th edition. UK: Blackwell Science. 2002; 597-601.

23. Sherwood L. Human physiology: From cells to systems. 2nd Edition. Jakarta: EGC. 2009; 669-75.

24. Snell RS. Clinical Anatomy. Edition 6. Jakarta: EGC. 2006; 721-47. 